\title{
EFEKTIVITAS COOPERATIVE LEARNING DALAM PEMBELAJARAN (STUDI PADA MAHASISWA SEMESTER 1 FAKULTAS PSIKOLOGI UNIVERSITAS X)
}

\author{
Ninawati ${ }^{1}$, Monika ${ }^{2}$ \\ ${ }^{1}$ Fakultas Psikologi, Universitas Tarumanagara, Jakarta \\ Email: ninawati@fpsi.untar.ac.id \\ ${ }^{2}$ Fakultas Psikologi, Universitas Tarumanagara, Jakarta \\ Email: monika@fpsi.untar.ac.id
}

\begin{abstract}
Cooperative learning is learning that occurs when students work in small groups to help one another in learning. In cooperative learning there are various approaches, one of wich is used this program si the Student Teams Achievement Division (STAD). In this progam a peer tutoring methos is carried out, namely the role of senior students who guide their junior students, as well as the role of peers in achieving progam goals, namely increasing the value of Child and Adolescent Developmental Psychology Subyects. This research was conducted on first semester students of the Faculty of Psychology, Universty X. The result showed that the interventions for two groups were not yet effective, this happened because there was ahigh likelihood of interaction between the test group and the control group. While based on the network pattern, it can be seen the changes in relations and interactions between students in each group and some students who become opinion leaders and there are students who become isolated.
\end{abstract}

Keywords: cooperative learning, STAD, peer tutoring

\begin{abstract}
ABSTRAK
Cooperative learning adalah pembelajaran yang terjadi ketika siswa atau mahasiswa bekerja dalam kelompok kecil untuk membantu satu sama lain dalam belajar. Pada cooperative learning terdapat berbagai pendekatan, salah satu di antaranya yang digunakan dalam program ini adalah Student Teams Achievement Division (STAD). Pada program ini dilakukan metode peer tutoring, yaitu adanya peran kakak asuh yang membimbing adik asuhnya, serta peran teman sebaya dalam mencapai tujuan program, yaitu meningkatkan nilai Mata Kuliah Psikologi Perkembangan Anak dan Remaja. Penelitian ini dilakukan pada mahasiswa semester 1 Fakultas Psikologi Universitas X. Hasil penelitian menunjukkan intervensi untuk kedua kelompok belum efektif, hal ini diduga terjadi karena interaksi antara kelompok uji dengan kelompok kontrol. Berdasarkan pola jaringan terlihat perubahan relasi dan interaksi antar mahasiswa pada masing-masing kelompok. Berdasarkan penelitian ditemukan beberapa mahasiswa menjadi pemuka pendapat dan beberapa menjadi pemencil.
\end{abstract}

Kata Kunci: cooperative learning, STAD, peer tutoring

\section{PENDAHULUAN}

\section{Latar Belakang}

Salah satu pendekatan belajar dalam psikologi pendidikan adalah social-constructivist, yaitu pendekatan yang menekankan pada konteks sosial dalam belajar dan sebuah ide yang mengatakan bahwa ilmu pengetahuan dibentuk dan dikonstruksi dari lingkungan sosial. Vygotsky (dalam Santrock, 2018) mengatakan bahwa guru sebaiknya menciptakan kesempatan pada para siswanya untuk kembali membangun ilmu pengetahuan bersama dengan guru dan teman-temannya. Cooperative learning yaitu pembelajaran yang terjadi ketika siswa atau mahasiswa bekerja dalam kelompok kecil untuk membantu satu sama lain dalam belajar. Cooperative learning ini dibagi lagi dalam berbagai bentuk diantaranya Student Teams Achievement Division (STAD), The jigsaw classroom, learning together, group investigation, dan coopertative scripting. Pada penelitian ini dilakukan cooperative learning dengan STAD (Santrock, 2018). 
STAD adalah suatu kelompok yang terdiri dari 4-5 orang siswa yang memiliki kemampuan yang berbeda-beda. Selanjutnya, setiap anggota kelompok ini akan belajar bersama, namun penilaian akan diambil secara individual. Penilaian kelompok akan diperoleh berdasarkan kontribusi dari masing-masing anggota kelompok. Selanjutnya, pada the jigsaw classroom, para siswa bekerja dalam satu kelompok kecil, lalu mereka membagi tugas setiap anggota mempelajari bagian tertentu dalam satu materi besar, lalu mereka bertemu kembali untuk menjelaskan bagian yang telah mereka pelajari pada teman-teman sekelompoknya (Santrock, 2018). Dalam penelitian yang dilakukan oleh Khan dan Inamullah (2011) di Pakistan ditemukan bahwa kelompok eksperimen yang menggunakan metode STAD, menunjukkan hasil tes yang lebih baik dibandingkan dengan hasil dari kelompok kontrol yang menggunakan metode pengajaran tradisional dalam pelajaran kimia pada level Sekolah Menengah Atas.

Demikian pula artikel yang ditulis Chan dan Idris (2017) yang telah menemukan sejumlah penelitian yang membuktikan efektivitas Cooperative Learning dengan metode STAD dalam meningkatkan performa siswa dalam pembelajaran matematika. Selain ditemukan peningkatan nilai atau prestasi dalam bidang matematika, ternyata STAD juga meningkatkan sikap yang positif siswa terhadap pembelajaran matematika itu sendiri, meningkatkan sikap positif antarsiswa, serta meningkatkan rasa percaya diri siswa dalam pelajaran matematika. Pada pelajaran Bahasa Inggris, Astuti dan Lammers (2017) juga menemukan bahwa cooperative learning dapat berkontribusi dalam meningkatkan kemampuan dalam pembelajaran bahasa kedua dan bahasa asing. Hasil dari penelitian tersebut ditemukan bahwa kegiatan dalam cooperative learning dapat meningkatkan kesempatan siswa dapat ikut berpartisipasi dalam menggunakan Bahasa Inggis di kelas. Keunggulan dari cooperative learning ini adalah adanya penilaian individual dan bukan hanya nilai kelompok yang diberikan. Dengan demikian, semua individu dalam kelompok akan berkontribusi dalam kelompok mereka.

Semua orang mempunyai lingkungan sosial dan terlibat dalam kegiatan sosial. Demikian pula pada mereka yang termasuk dalam kelompok usia remaja (antara 16-19 tahun), melakukan kegiatan atau bergaul hanya dengan keluarga saja tentunya belum dianggap mencukupi, mungkin terjadi karena ada ketidakcocokan usia bahkan ketidakcocokan dalam hobby dan pilihan-pilihan lainnya (Rakhmat, 2000). Dalam konteks perguruan tinggi, khususnya pada mahasiswa, terutama sebagai mahasiswa yang baru diterima di sebuah perguruan tinggi, maka mereka pada umumnya perlu mencari relasi yang baru. Selain karena kebutuhan bersosialisasi sebagai makhluk sosial, kegiatan sebagai mahasiswa menuntut pula sosialisasi yang "ditugaskan" oleh fakultas, misalnya beberapa mata kuliah yang mengharuskan ada pekerjaan kelompok, diskusi kelompok dan beberapa kegiatan lainnya.

Para mahasiswa akan memiliki interaksi dengan sesama mahasiswa lainnya. Shaffer (1994) menjelaskan tentang peranan teman sebaya kepada remaja sebagai berikut: a) teman sebaya sebagai penguat sosial, b) teman sebaya sebagai model tingkah laku remaja, c) teman sebaya sebagai obyek dalam perbandingan sosial, dan d) teman sebaya sebagai pengkritik dan agen untuk meyakinkan anggotanya. Dalam perkuliahan tentunya para mahasiswa terlibat dalam berbagai interaksi sesuai dengan informasi yang dipertukarkan. Begitu juga ketika berinteraksi (berhubungan) dengan sesama mahasiswa. Pada pendekatan social constructivist, terdapat suatu bentuk pembelajaran yang disebut dengan cooperative learning yaitu pembelajaran yang terjadi ketika siswa atau mahasiswa bekerja dalam kelompok kecil untuk membantu satu sama lain dalam belajar. Cooperative learning ini dibagi lagi dalam berbagai bentuk di antaranya Student Teams Achievement Division (STAD), The jigsaw classroom, learning together, group investigation, dan coopertative scripting. Pada penelitian ini dilakukan cooperative learning 
dengan STAD. STAD adalah suatu kelompok yang terdiri dari 4-5 orang siswa yang memiliki kemampuan yang berbeda-beda. Selanjutnya, setiap anggota kelompok ini akan belajar bersama, namun penilaian akan diambil secara individual. Penilaian kelompok akan diperoleh berdasarkan kontribusi dari masing-masing anggota kelompok.

Pada penelitian ini ingin dilihat bagaimana efektivitas cooperative learning ini dalam pembelajaran salah satu mata kuliah, yaitu Mata Kuliah Psikologi Perkembangan Anak dan Remaja.

Dengan demikian permasalahannya adalah (1) Bagaimana efektivitas cooperative learning ini dalam pembelajaran salah satu mata kuliah, yaitu Mata Kuliah Psikologi Perkembangan Anak dan Remaja?; (2) Apakah ada perbedaan hasil nilai pembelajaran pada mahasiswa yang mendapatkan cooperative learning dan yang tidak?; (3) Bagaimana perbedaan jaringan interaksi mahasiswa sebagai mahasiswa baru setelah satu semester mereka bergaul?

\section{METODE PENELITIAN}

Desain penelitian ini adalah penelitian eksperimen dengan dua kelompok yaitu kelompok uji dan kelompok kontrol. Kelompok uji terdiri dari dua kelas dengan masing-masing 30 mahasiswa, demikian juga pada kelompok kontrol. Partisipan dalam penelitian ini adalah mahasiswa Fakultas Psikologi angkatan tahun akademik 2017/2018 dari tempat kelompok PA. Setting penelitian adalah di Fakultas Psikologi Universitas X. Variabel yang diukur adalah peningkatan nilai Mata Kuliah Psikologi Perkembangan Anak dan Remaja dari nilai UTS ke nilai UAS, sehingga diperlukan nilai yang akan dipinjam ke program studi S1 Fakultas Psikologi Universitas Tarumangara.

Penelitian dilaksanakan pada saat kuliah berlangsung, informed consent dibagikan kepada mahasiswa sebelum pengisian kuesioner. Semua partisipan yang hadir pada perkuliahan saat kuesioner disebarkan, menyatakan kesediaannya, karena pertanyaan yang perlu diisi adalah tentang aktivitas mereka di kelas. Mahasiswa yang kebetulan berhalangan hadir pada saat kuesioner dibagikan, diminta mengisi pada hari lain, sampai jumlah yang diperlukan terpenuhi. Partisipan yang terlibat tidak mendapatkan imbalan karena keterbatasan dana penelitian yang diterima.

Pengumpulan data juga dilakukan melalui kuesioner yang terdiri dari empat bagian. Pertama, berisi identitas partisipan. Yakni nama, hobi, asal sekolah (kota). Kedua, pilihan hubungan partisipan ketika ia berbicara/bertanya tentang masalah "perkuliahan" dan masalah pribadi. Partisipan diminta memilih maksimal tiga nama sesama peserta kuliah yang terdaftar, nama peserta kuliah disertakan pada lembar kuesioner. Pengumpulan data dilakukan dengan membandingkan nilai UTS sebagai pretest, dan nilai UAS sebagai posttest sebagai kriteria keberhasilan dari efektivitas cooperative learning pada pembelajaran Mata Kuliah Psikologi Perkembangan Anak dan Remaja ini. Perlakuan yang diberikan pada penelitian eksperimen ini adalah dengan mengadakan kegiatan belajar bersama dalam kelompok kecil (lima orang per kelompok) dalam menghadapi dan mempersiapkan UAS (Ujian Akhir Semester). Setiap kelompok didampingi oleh satu kakak kelas yang berperan sebagai tutor dalam kelompok tersebut. Selanjutnya, mereka belajar bersama dengan tutor dan dengan teman sebaya (peer) untuk memahami materi dalam perkuliahan tersebut. Setelah nilai UAS Mata Kuliah Psikologi Anak dan Remaja dikeluarkan oleh dosen, maka akan dihitung perbedaan nilai UTS dan UAS. Kontribusi setiap anggota kelompok terhadap peningkatan nilai dari UTS ke UAS tersebut akan digunakan sebagai kriteria keberhasilan atau efektivitas program ini. Selain itu juga dilakukan analisis terhadap pola jaringan pada para mahasiswa ini. Analisis dilakukan dalam tiga tahap. Pertama, untuk mengetahui pola jaringan. Kedua, untuk mengetahui pola jaringan di tingkat klik. Ketiga, untuk mengetahui pola sebagai pemuka pendapat. 


\section{HASIL DAN PEMBAHASAN}

Partisipan penelitian ini berjumlah 120 orang, yang terdiri dari empat kelompok. Pengelompokkan dilakukan berdasarkan kelompok mahasiswa dalam proses Pembimbingan Akademik yang difasilitasi oleh satu orang dosen, setiap kelompok terdiri dari 30 orang. Berdasarkan hasil uji normalitas one sample Kolmogorov-Smirnov diperoleh hasil uji 0.010 dengan nilai $\mathrm{p}>0.05$ maka dapat dinyatakan sebaran data normal. Pengujian baik pada kelompok uji maupun kelompok kontrol dilakukan dengan membandingkan nilai UTS dan nilai UAS Mata Kuliah Psikologi Anak dan Remaja. Hasil pengujiannya sebagai berikut:

Tabel 1. Hasil uji statistika

\begin{tabular}{lccccccc}
\hline Kelompok & F & Sig. & T & df & Sig. & $\begin{array}{c}\text { Mean } \\
\text { UTS }\end{array}$ & Mean UAS \\
\hline Uji & 0,015 & 0,901 & $-5,051$ & 118 & 0,000 & 59,5333 & 71,2667 \\
Kontrol & 7,899 & 0,006 & $-5,485$ & 105,030 & 0,000 & 59,7500 & 73,3000 \\
\hline
\end{tabular}

Dari hasil pengujian dapat dikatakan bahwa ada perbedaan yang signifikan antara nilai UTS dan nilai UAS baik pada kelompok uji maupun kelompok kontrol. Jika dilihat dari nilai rata-rata UTS pada kelompok uji dan kelompok kontrol menunjuukan angka yang hampir sama. Pada kelompok uji diperoleh rata-rata nilai UTS 59.5333 dan pada kelompok kontrol 59,7500. Demikian pula nilai rata-rata UAS diperoleh nilai yang hampir sama besarnya, kelompok uji memiliki nilai rata-ratanya 71,2667 dan nilai kelompok kontrol rata-ratanya 73,3000. Dengan adanya kenaikan nilai rata-rata pada UTS dan UAS pada kelompok uji dan kelompok kontrol yang hampir sama, maka terlihat pada kelompok uji dan kelompok kontrol ada perbedaan yang signifikan nilai mahasiswa.

Intervensi yang diberikan dengan metode peer tutoring untuk kedua kelompok ini dapat dikatakan belum efektif. Hal ini terjadi karena mungkin ada kesadaran dari para mahasiswa bahwa nilai UAS harus lebih baik dari nilai UTS. Di Fakultas Psikologi pada umumnya nilai UTS diumumkan secara eksplisit sehingga mahasiswa dapat menyadari jumlah nilai yang diperlukan untuk lulus dari mata kuliah yang diikutinya. Kondisi ini yang akan membuat mahasiswa menjadi giat belajar untuk menambah nilai atau memperbaiki nilai yang diperoleh pada saat UTS. Pada kelompok uji dengan sengaja dibentuk kelompok belajar untuk memperbaiki dan meningkatkan nilai UTS nya. Sementara itu pada kelompok kontrol tidak dibentuk kelompok belajar, namun bukan tidak mungkin akan terjadi juga kelompok-kelompok belajar yang dibentuk oleh pada mahasiswa.

Ada kemungkinan para mahasiswa berinteraksi antara kelompok uji dengan kelompok kontrol. Hal ini amat mungkin terjadi karena kelompok uji dan kelompok kontrol berada pada kelas yang membaur pada mata kuliah yang diampunya. Kelompok uji dan kelompokn kontrol tidak berada pada satu kelas mata kuliah yang dijalaninya.

\section{Interaksi Sosial Berdasarkan Pola Jaringan}

Berdasarkan pola jaringan yang diujikan kepada para mahasiswa dipilih dua topik yaitu interaksi antarteman, dan interaksi pada masalah perkuliahan. Gambaran selengkapnya dapat dilihat pada sosiogram (1-8). Pada kelompok 1 terdapat 3 klik pada interaksi antarteman, dan 4 klik pada interaksi tentang perkuliahan. Penghbung klik ada lima orang pada interaksi antarteman, dan empat orang (dua pasangan) pada interaksi tentang perkuliahan. Pemuka pendapat (opinion leader) masing-masing satu orang baik pada interaksi antarteman maupun pada interaksi 
tetnang perkuliahan. Sedangkan isolate (pemencil) ada lima orang pada interaksi antarteman, dan satu orang pada interaksi tentang perkuliahan.

Pada kelompok 2 terdapat tiga klik dalam interaksi antarteman, dan dua klik pada interaksi tentang perkuliahan. Penghubung klik hanya ada sepasang pada interaksi antarteman, pada interaksi tentang perkuliahan tidak ada penghubung klik. Pemuka pendapat ada dua orang pada interaksi antarteman, dan tiga orang pada interaksi tentang perkuliahan.isolate tidak ditemukan pada kelompok 2 ini. Pada kelompok 3 ditemukan empat klik pada interaksi antarteman dan dua klik pada interaksi tentang perkuliahan. Penghubung klik pada interaksi antarteman ada dua pasang (4 orang), dan pada interaksi tentang perkulihan ada sepasang (dua orang). Pemuka pendapat tidak ditemukan pada kelompok 3 ini, baik pada interaksi antarteman maupun interaksi tentang perkuliahan. Isolate pada interaksi antarteman ada lima orang, demikian pula pada interaksi tentang perkuliahan ada lima orang isolate.

Tabel 2. Pola interaksi antar teman dan perkuliahan pada empat kelompok

\begin{tabular}{llcccccccc}
\hline no & Indikator & \multicolumn{2}{c}{ Kelompok 1 } & \multicolumn{2}{c}{ Kelompok 2 } & \multicolumn{2}{c}{ Kelompok 3 } & \multicolumn{2}{c}{ Kelompok 4 } \\
\cline { 2 - 8 } & & teman & kuliah & teman & Kuliah & Teman & kuliah & teman & kuliah \\
\hline 1 & Jumlah klik & 3 & 4 & 3 & 2 & 4 & 2 & 4 & 4 \\
2 & $\begin{array}{l}\text { Penghubung } \\
\text { klik }\end{array}$ & $9 / 7 ; 23 ;$ & $6 / 20 ;$ & $24 / 26$ & ---- & $19 / 16 ;$ & $5 / 10$ & $22 / 18$ & $22 / 18 ; 15 / 4 ;$ \\
& $6 / 20$ & $13 / 15$ & & & $10 / 5$ & & & $27 / 2 ; 14 / 26 ;$ \\
3 & Pemuka & 12 & 13 & 11,26 & 11, & ----- & ----- & 9,21 & 9,25 \\
& $\begin{array}{l}\text { pendapat*) } \\
4\end{array}$ & & & & 14,19 & & & & \\
& Isolate & $1,5,14$, & 29 & ----- & ---- & $4,6,7$, & $4,6,7$, & $5,6,8$, & 5,12 \\
& 27,29 & & & & 17,29 & 17,22 & 12,30 & \\
\hline
\end{tabular}

Keterangan: *) dipilih oleh lima orang atau lebih

Angka pada indikator penghubung klik, pemuka pendapat dan isolate adalah angka yang merujuk pada nomor responden yang terlibat.

Pada kelompok 4 terdapat empat klik pada interaksi antarteman, demikian pula pada interaksi tentang perkuliahan terdapat empat klik. Penghubung klik terdapat sepasang ( 2 orang) pada interaksi antarteman, dan lima pasang (10 orang) pada interaksi tentang perkuliahan. Pemuka pendapat masing-masing ada dua orang pada interaksi antarteman dan interaksi tentang perkuliahan. Isolate ditemukan lima orang pada interaksi antarteman, dan dua orang pada interaksi tentang perkuliahan.

Dalam penyelenggaraan perkuliahan seyogyanya mahasiswa saling terhubung satu dengan lainnya, terutama dalam pengerjaan tugas kelompok pada mata kuliah tertentu memerlukan kerjasama antarteman. Pada pola jaringan di penelitian ini terlihat beberapa mahasiswa berada pada posisi pemencil (isolate), artinya mereka tidak memilih dan dipilih sebagai teman dan ketika berkomunikasi tentang perkuliahan. Dari empat kelompok penelitian, hanya pada kelompok 2 yang tidak memiliki mahasiswa sebagai pemencil. Mengacu pada hasil penelitian Astuti dan Lammers (2017) dalam pelajaran bBahasa Inggris menemukan bahwa cooperative learning dapat berkontribusi dalam meningkatkan kemampuan dalam pembelajaran bahasa kedua dan bahasa asing. Pada penelitian ini belum terlihat perbedaan peningkatan kemampuan tersebut, mungkin terjadi karena mata kuliah ini tidak mempraktikkan keterampilannya. Shaffer (1994) menjelaskan tentang peranan teman sebaya kepada remaja sebagai berikut: a) teman sebaya sebagai penguat sosial, b) teman sebaya sebagai model tingkah laku remaja, c) teman sebaya sebagai obyek dalam perbandingan sosial, dan d) teman sebaya sebagai pengkritik dan 
agen untuk meyakinkan anggotanya. Dengan demikian, seperti terlihat pada hasil penelitian, setiap kelompok memiliki klik, yang dapat dikatakan sesuai dengan pendapat Shaffer bahwa remaja memerlukan teman sebaya sebagai penguat sosial.

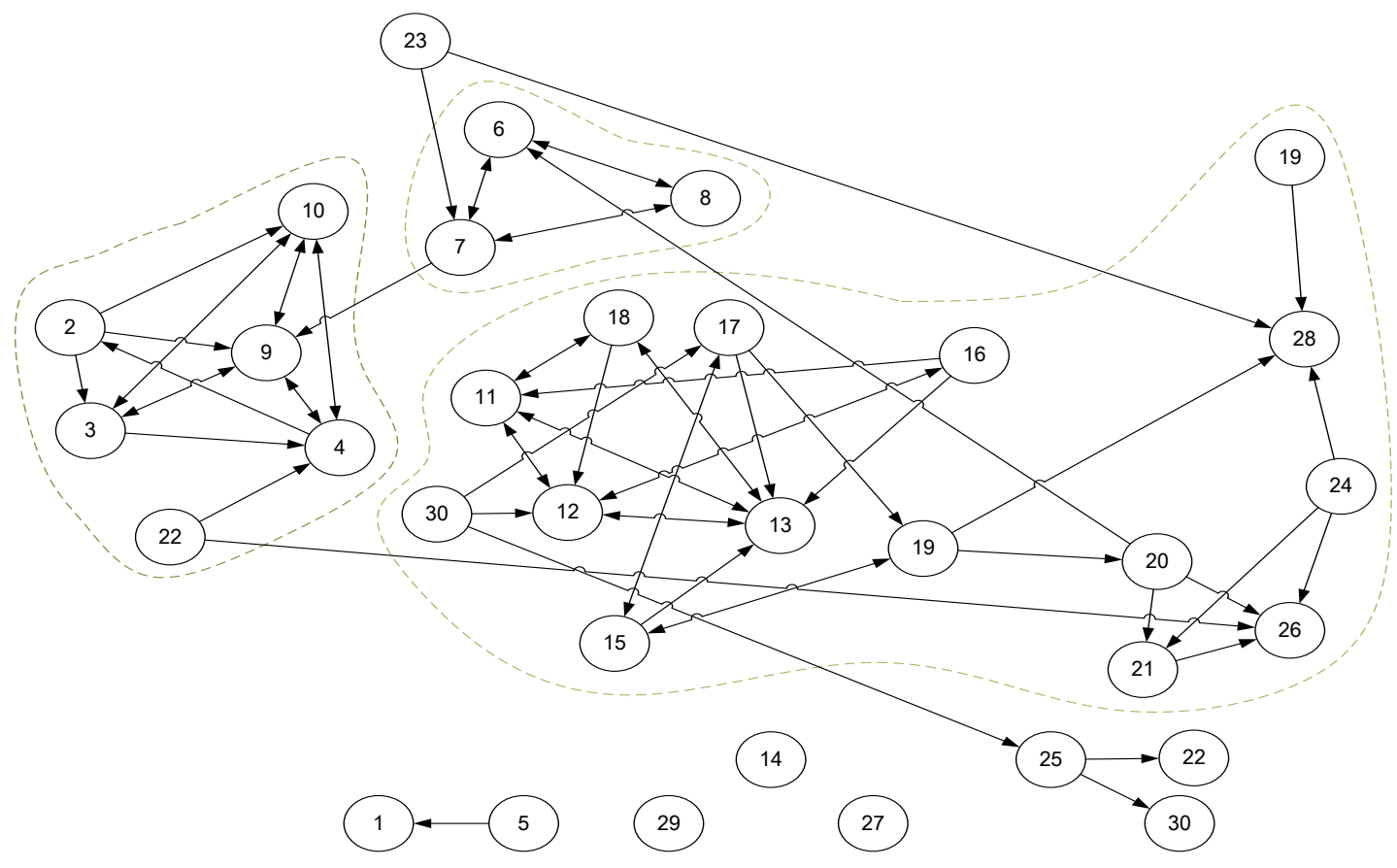

Sosiogram 1. Interaksi antrateman dari kelompok 1

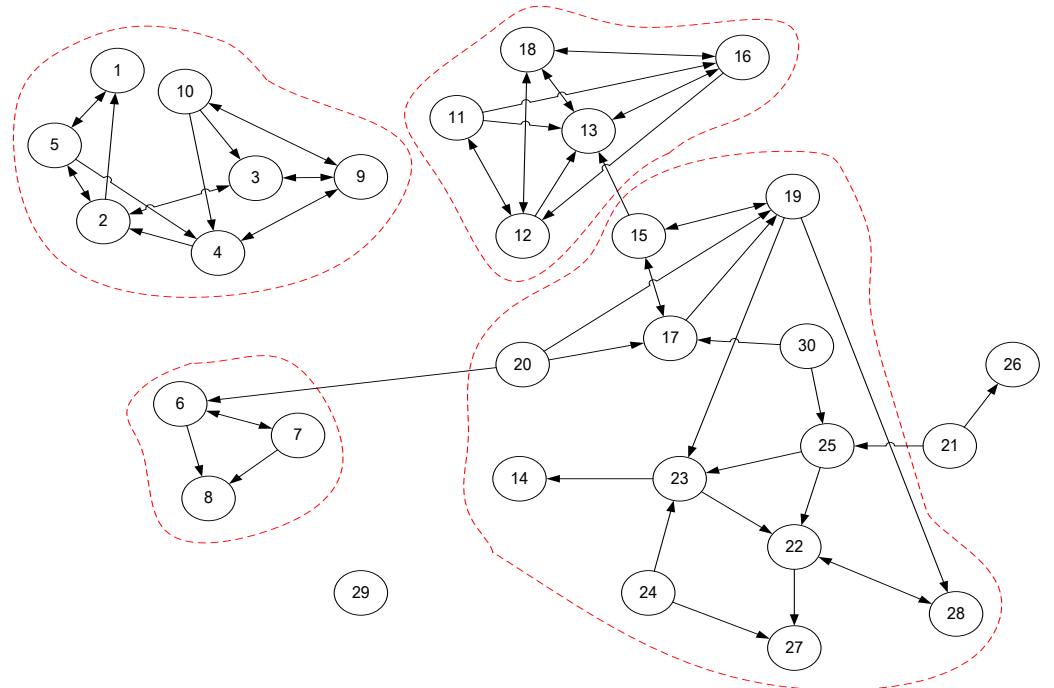

Sosiogram 2. Interaksi tentang pembahasan perkuliahan dari kelompok 1 


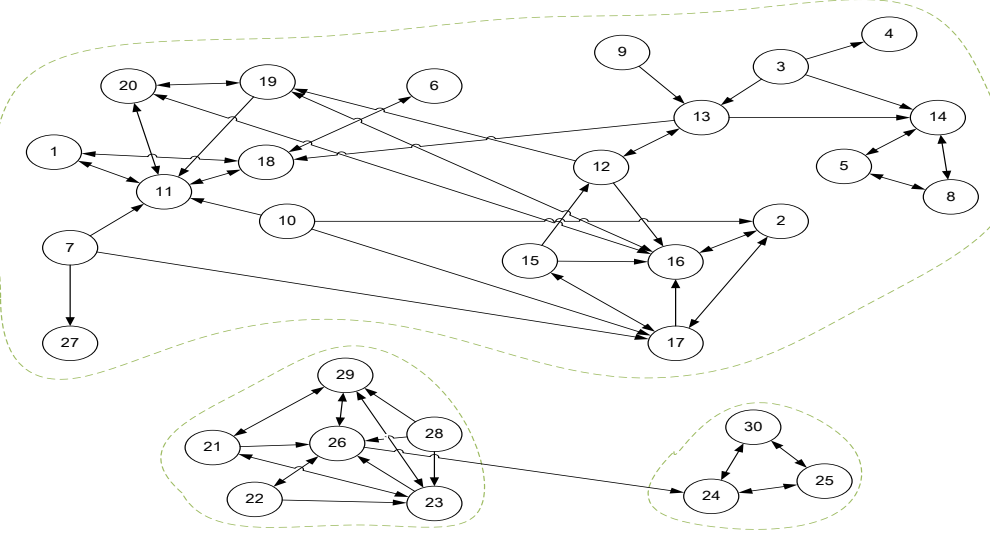

Sosiogram 3. Interaksi antrateman dari kelompok 2

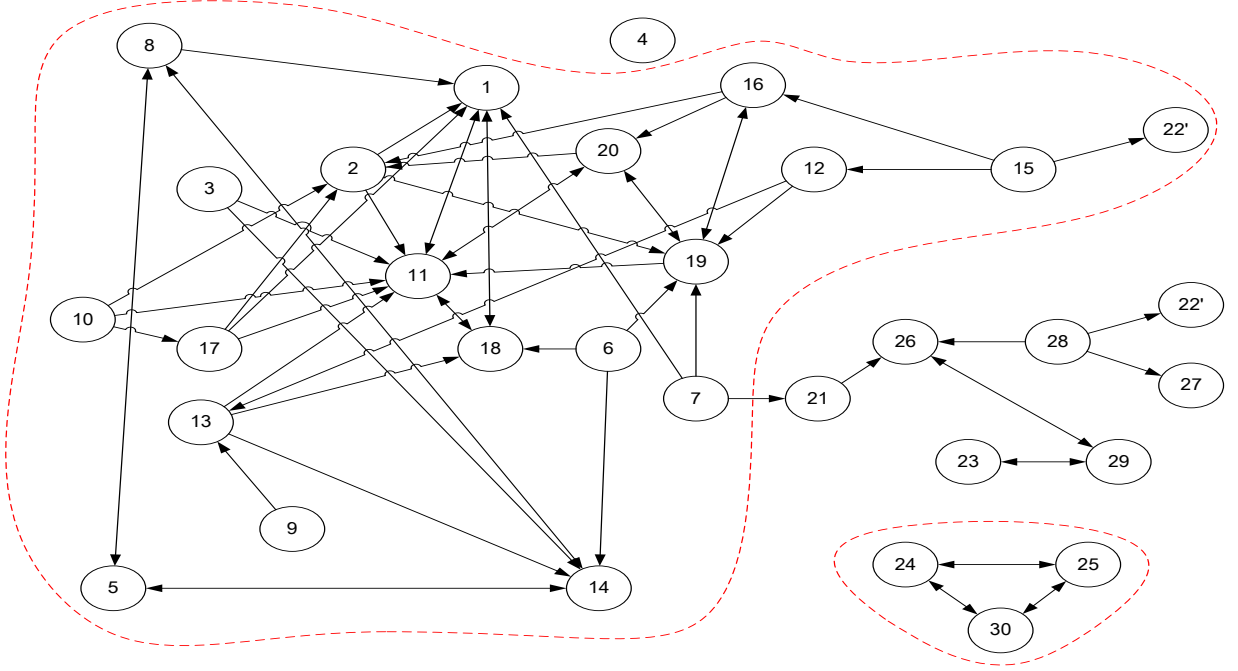

Sosiogram 4. Interaksi tentang pembahasan perkuliahan dari kelompok 2

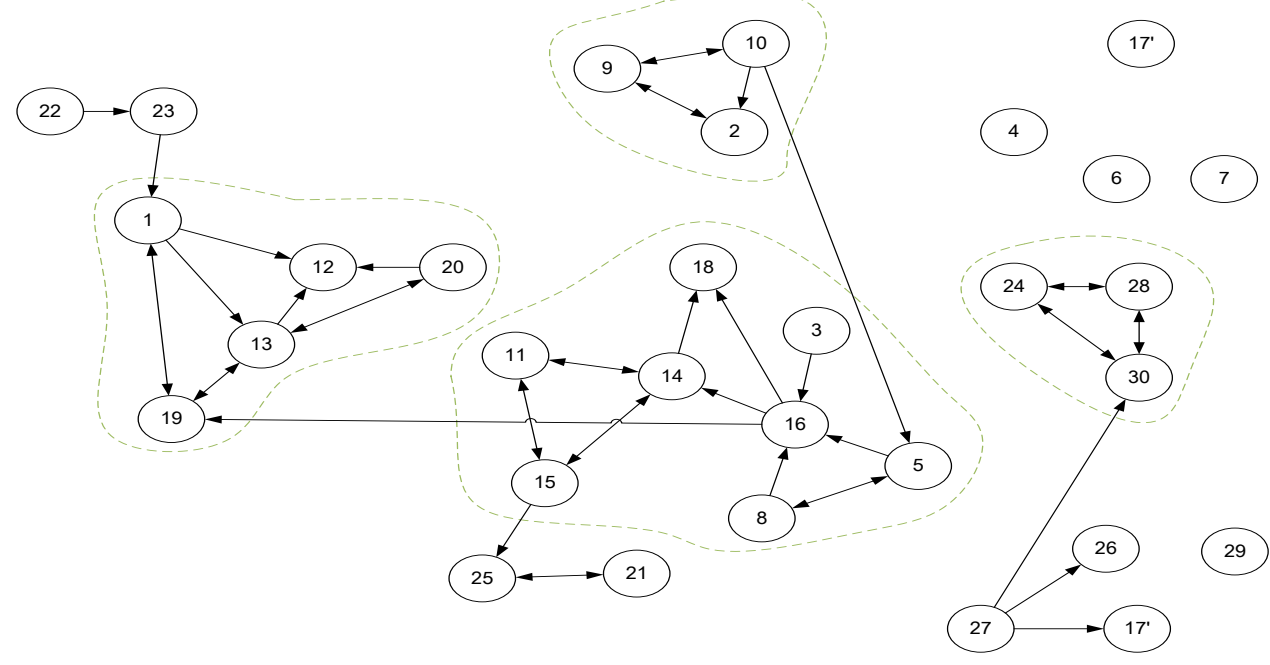

Sosiogram 5. Interaksi antrateman dari kelompok 3 


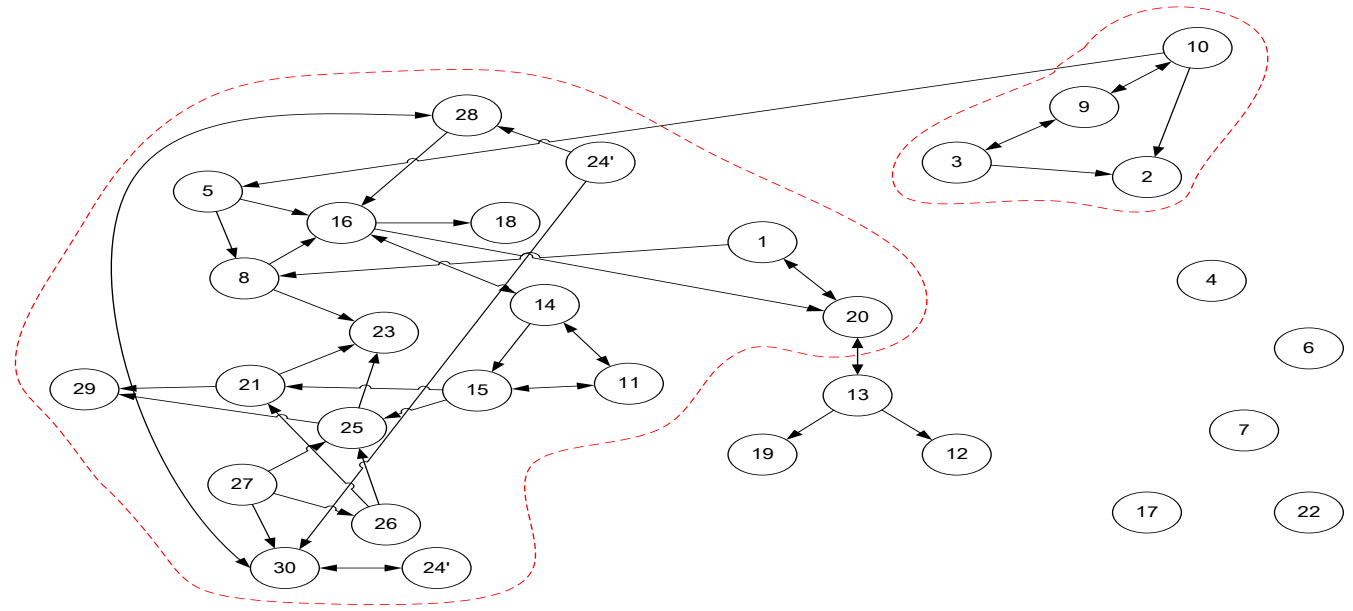

Sosiogram 6. Interaksi tentang pembahasan perkuliahan dari kelompok 3

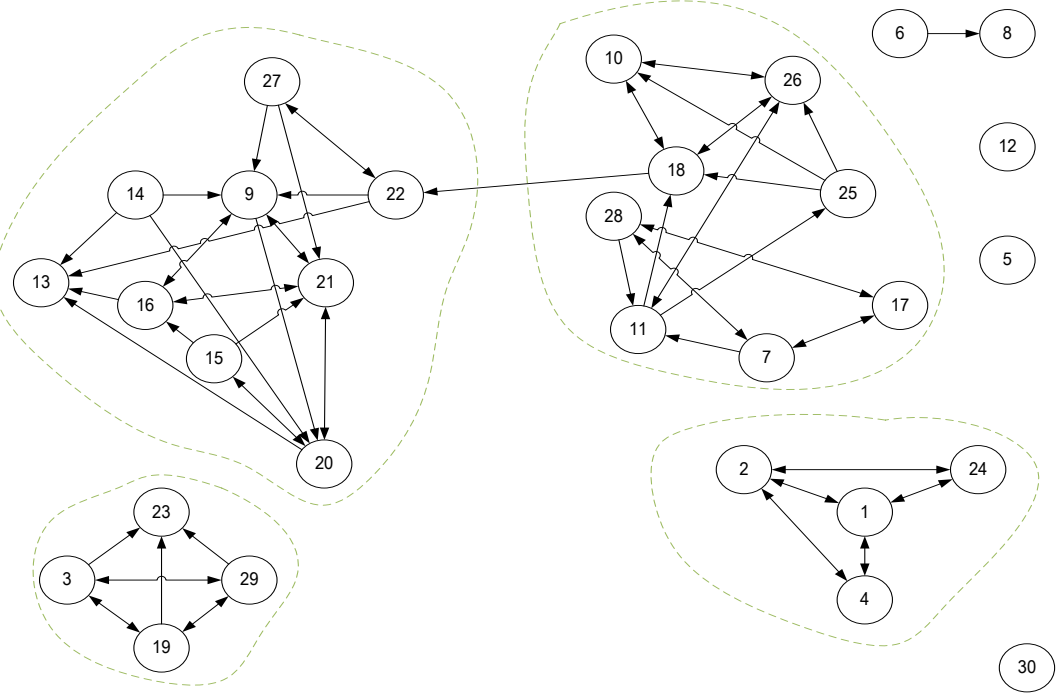

Sosiogram 7. Interaksi antrateman dari kelompok 4

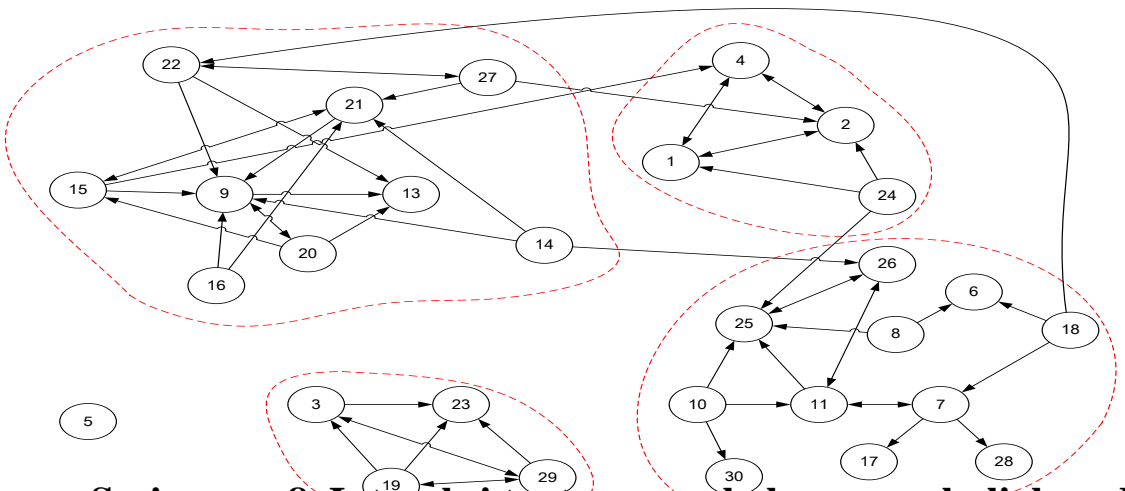

Sosiogram 8. Interaksi tentang pembahasañ perkuliahan dari kelompok 4 


\section{KESIMPULAN DAN SARAN}

Dari hasil pengujian statistika untuk mengukur efektivitas peer tutoring pada kelompok uji dapat dikatakan belum berhasil, karena pada kelompok yang tidak mendapatkan peer tutoring juga menghasilkan perbedaan nilai UTS dan nilai UAS yang meningkat. Hal ini terjadi karena beberapa hal: (a) Kesadaran mahasiswa relatif tinggi, untuk mendapatkan nilai lebih baik daripada nilai UTS, sehingga ada peningkatan yang signifikan perolehan nilainya, (b) mahasiswa yang berada dalam kelompok uji dan kelompok kontrol dapat berinteraksi arena mereka berbaur kelas yang diikutinya, dan (c) kemungkinan berkomunikasi antara mahasiswa dari kelompok uji dan kelompok kontrol amat terbuka.

Dari hasil pengolahan data melalui matriks dan sosiogram interaksi antarteman dan interaksi tentang masalah perkuliahan, pada dasarnya semua kelompok jaringan tidak terintegrasi, semuanya memiliki klik. Namun, walaupun setiap jaringan memiliki beberapa klik, di antara klik ditemukan penghubung klik. Penghubung klik pada umumnya merupakan penghubung yang berpasangan. Pada kelompok 2 interaksi tentang masalah perkuliahan tidak ditemukan penghubung klik. Pemuka pendapat (yang dapat dipakai sebagai penyebar informasi dan mungkin juga sebagai tempat bertanya) pada masing-masing jaringan ditemukan tidak terlalu banyak, hanya ada satu atau dua orang pemuka pendapat. Bahkan pada kelompok 3 tidak ada pemuka pendapat, baik pada interaksi antarteman maupun interaksi tentang masalah perkuliahan.

Penelitian ini merupakan penelitian lanjutan dari semester ganjil dan semester genap. Dari hasil yang diperoleh maka diperlukan perhatian yang lebih mendalam terhadap mahasiswa tertentu yang ditemukan berdasarkan pola jaringannya. Untuk itu penelitian selanjutnya perlu dilakukan dengan beberapa hal:

a. Penelitian kualitatif dengan partisipan mahasiswa yang menjadi pemuka pendapat dan mahasiswa yang isolate.

b. Penelitian yang sama dilakukan untuk mahasiswa baru angkatan 2018/1019 dengan pola yang sama untuk menemukan pola jaringan yang mungkin sama sebagai tipekal mahasiswa di kota besar.

c. Membuat program untuk para dosen pembimbing Penasehat Akademik, untuk memberikan perhatian (treatment) khusus kepada mahasiswa yang memerlukannya.

Fakultas yang menaungi seluruh mahasiswa dapat memberikan perhatian lebih fokus kepada mahasiswa yang memerlukannya dari sejak dini sehingga dapat mengurangi resiko mahasiswa drop out. Selain memberikan perhatian kepada mahasiswa yang memerlukannya, perlu juga dipikirkan tentang informasi yang disampaikan dan cara penyampaiannya dengan memperhatikan siapa yang dapat dipakai sebagai sumber informasi.

\section{Ucapan Terima Kasih}

Penulis mengucapkan terima kasih kepada Ketua Lembaga Penelitian dan Pengabdian kepada Masyarakat Universitas Tarumanagara yang telah menyetujui pelaksanaan penelitian ini, dan kepada para mahasiswa Fakultas Psikologi Universitas X tahun akademik 2017/2018 yang ikut berpartisipasi dalam penelitian ini.

\section{REFERENSI}

Astuti, P \& Lammers, J.C. (2017). Individual accountability in cooperative learning: more opportunities to produce spoken English. E-journal of Indonesian Journal of Applied Linguistic, $\quad 7(1), \quad 215-228 . \quad$ Diunduh dari http://ejournal.upi.edu/index.php/IJAL/article/view/6878

Baumeister, R.F., \& Bushman, B.J. (2014). Social psychology and human nature (3rd ed.). New York, NY: Wadsworth, Cengage Learning 
Buku Panduan Masa Pembinaan Mahasiswa Baru (2017). Jakarta: Fakultas Psikologi Universitas Tarumanagara

Chan, L.L. \& Idris, N. (2017). Cooperative Leaning in Mathematics Education. International Journal of Academic Research in Business and Social Sciences, 7, 539-553. doi: 10.6007/IJARBSS/v7-i3/2757

Effendi (1993). Ilmu, teori dan filsafat komunikasi. Bandung: Cipta Aditya Bakti.

Gunarsa \& Gunarsa (2009). Psikologi remaja. Jakarta: Gunung Mulia

Hjelle, L.A. \& Ziegler, D.J. (1981). Personality theories: Basic assumptions, research and application ( $2^{\text {nd }}$ editon). Singapore: McGraw-Hill Book Co.

Muijs, D \& Reynolds, D (2011). Effective teaching: Evidence and practice. London: Sage.

Myers, D.G. (2010). Social psychology (10 ${ }^{\text {th }}$ edition). Boston, LA: McGraw-Hill.

Khan, G.N \& Inamullah, H.M. (2011). Effects on Student's Team Achievement Division on Academic Achievement of Students. Asian Social Sciences, 12, 212-215. doi:10.5539/ass.v7n12p211

Ormrod, J.E. (2009). Psikologi pendidikan: Membantu siswa tumbuh dan berkembang. Edisi Keenam. Jilid 2. Jakarta, INA: Erlangga.

Rakhmat (2000). Psikologi komunikasi. Bandung: Remaja Rosdakarya Offset.

Rogers, E.M. \& Kincaid, D. (1981). Communication network, toward a new paradigm for research. New York, NY: The Free Press.

Santrock, J.W. (2018). Educational psychology. (6th ed). New York, NY: McGraw Hill.

Schunk, D.H. (2014). Learning theories an educational perspective. (6th ed). New York, NY: Pearson.

Shaffer, D.R. (1994) Social and personality development (3 ${ }^{\text {rd }}$ ed). California, CA: Broks

Supratiknya, A. (1995). Komunikasi antarpribadi tinjauan psikologis. Yogyakarta: Kanisius

Wasserman, S. \& Faust, K. (1999). Social network analysis: Methods and applications. New York, NY: Cambridge University Press. 